\title{
CANADA AS A VASSAL STATE
}

$\mathrm{F}^{\mathrm{O}}$

R the thoughtful observer of our domestic politics even the gloom of the world situation has been sensibly lightened by noting the eagerness with which the so-called Autonomists of Canada have for years been following a false scent, and the vehemence with which they are barking up the wrong tree. What they pretend to fear is being dragged at the wheels of empire. England is the enemy, or rather a desperate knot of modern Machiavellis who are plotting at the centre (with The Round Table for ally) to enslave our beloved Dominion, or at least to limit our powers of self-determination. Now, when a man begins to cherish delusions, to believe himself to be the victim of a widespread mysterious conspiracy, it is time to call in the nerve specialist. That way madness lies. Nor is it less true of a group of men and an organized propaganda.

Does any sane man, woman, or child in Canada really believe that Great Britain would send one ship, or fire a single gun, to retain our country in the bonds of unwilling allegiance? To put the question is to answer it. The situation is unthinkable.

What is even more amusing than all this misdirected energy of the Autonomists is their blindness, a blindness shared by most Canadians, to the very real danger of bondage to another power. That power is the United States of America.

The threats of American politicians, editors, and Fourth of July orators, the organized effort for "commercial union" in 1891, the avowed purpose of the Dingley tariff, the possibility of a quarrel between Canada and the United States ending in an appeal to arms, may be lightly dismissed. The danger is far more subtle and far more deeply to be dreaded. It lies in gradual assimilation, in peaceful penetration, in a spiritual bondage-the subjection of the Canadian nation's mind and soul to the mind and soul of the United States. No long argument is needed to prove the imminent and deadly menace of this danger, and nothing should touch the pride of a young, strong, and ambitious people 
like accepting tamely a position of inferiority to a powerful neighbour. Without any outward fetter it is the situation of a spiritual slave. Enforced political subjection is the lesser evil; it would be easier to bear, for the spirit could still be free.

Historically, Canada is a by-product of the United States. The American "plantations" were never at their ease as long as the power of France was enthroned at Quebec. It was largely through their activity that the Golden Lilies gave place to St. George's Cross; then, as Parkman points out, the road to independence was open. The successful rebellion of the Thirteen Colonies created Ontario, whither were driven the upholders of a lost cause and a sullied flag. And Ontario made the three prairie provinces. The expulsion of the Loyalists also created the province of New Brunswick, and set an ineffaceable mark upon Nova Scotia. At the present time the most progressive, intelligent and desirable immigrants into our West are Americans. What our histories do not teach, and what our people do not realize, is how many Americans, who were anything but Loyalists, settled in Canada, and how strong, from the very beginning, has been the drag towards the United States. Few realize that one county of loyal Nova Scotia sent delegates to the Philadelphia Congress of 1776, that there was a tea riot in Halifax, and that part of the population were active "sympathizers" with the "rebels" all through the Revolutionary War. General Cruikshank has shown how large was the disloyal element of American settlers in Ontario during the war of 1812. If the political "unpleasantness" of 1837 had reached its consummation, if Papineau and Mackenzie could have worked their will, Ontario and Quebec would now be states in the American union. It may be fairly argued that they were patriotic leaders, wise statesmen far in advance of their time, anticipating Goldwin Smith in their vision of Canada's manifest destiny, and that they will be justified by history. In the mean time, let their activities serve as illustration of the political "set" towards the United States. Another is the avowed movement towards annexation in 1849. There are Canadians who are not proud that their forebears signed the Montreal manifesto. Lord Elgin wrote that annexation was considered to be the remedy for every kind of Canadian discontent. He wás haunted by the fear of it all through his tenure of office. Annexation had been preached by the radical journals for years; and it was confidently expected by politicians in the United States. The latest attempt at this form of national suicide was in 1891, and 
it revolted the soul of Edward Blake. These facts indicate how currents of political thought have run. All are symptoms of the same general tendency of the greater to absorb the less. The sucking wave created by the passage of a huge liner through the water drags small craft into its wake. The New York drew H.M.S. Gladiator into its sphere of influence, with disastrous results. Which things are a parable.

It is inevitable that the United States should exert a tremendous influence upon Canada. Our domains march together for three thousand miles. The same speech, the same laws, the same religions prevail on both sides of the border, as Goldwin Smith was never weary of preaching. Intercourse between the countries is easy. A standard gauge and common courtesy have made the continent one country for purposes of railway transportation. C.P.R. cars may be seen in Texas, and Omaha and Santa Fé in Cape Breton. Traffic between Canada and the United States is far easier than between the separate colonies of the Australian Commonwealth. Then, our neighbours are many and rich; we are few in the land, and until lately we were very poor. Hundreds of thousands of Canadians have been drawn across the border, because of the better opportunities for making a living, and for making money, under the Stars and Stripes. All these things were inevitable, and tend to make of Canada nine more states not yet brought formally under the control of Washington.

But our spiritual subjection goes deeper. Canada has definitely, if tacitly, declared her position as between American and English ideals. To begin with the individual. The most popular set of caricatures ever designed in this country were Racey's protrayal of the green "young Englishman" and his mistakes, much as the "new chum" is represented in Australia. The Englishman's accent, voice, manner, clothes are considered odd, departing from the norm. The American's are not, because they do not strike us as different from our own.

Take the most potent influence at work to-day upon the popular mind, our journalism. Hundreds of thousands of Canadians read nothing but the daily newspaper. Not only is the Canadian newspaper built on American lines, but it is crammed with American "boiler-plate" of all kinds, American illustrations, American comic supplements. American magazines, some of them distinctly anti-British in tone and tendency, flood our shops and book-stalls. Every new Canadian magazine is on an Ameri- 
can model, some of them borrowing an American title and changing only the national adjective. The Week, founded on the English model, is dead; and so is The University Magazine.

Another potent influence for bringing Canada into spiritual subjection to the United States is the moving-picture show. The films are made for American audiences, naturally, to suit their taste. Then, they come to Canada. We originate none, practically. I dropped into a "movie" theatre in a small Nova Scotian town. It was filled with noisy, excited children. The point of the plot was the continual thwarting of a villain through the agency of several small boys and girls. They occurred and recurred in a sort of procession, the leader carrying the Stars and Stripes; and whenever they appeared the little Bluenoses cheered like mad.

The case of Capital and Labour in Canada is notorious. Selfdetermination is a joke. The price of our steel products is fixed in New York, and our Nova Scotia miners obey the orders of a Vehmgericht in Indianapolis. The protective tariff has forced many American firms to establish branches in Canada. A large part of our prosperity is due to this exhibition of American enterprise, and not to the initiative of our own business men. Our business methods are American, with the exception of our great banking system.

American influence is seen even more plainly in our universities. The curriculum, text-books, methods of teaching, oversight of students, "credits," are borrowed from the United States. Organization and administration are on the American model. Among the students, American ideas prevail. Such matters as Greek letter societies, class organizations, with president, prophet, critic, and "exercises," down to the big initial on the football sweater and the curious war-cries known as class and college yells, are borrowed directly from American colleges. Our students did not originate these ideas; they borrowed them. The Dalhousie "yell," for example, was introduced by an American teacher of music.

Canadian sport has become more and more American. Our one native game, lacrosse, is dead. Cricket, which flourishes in Australia, is here a sickly exotic. But baseball is everywhere. Our newspapers are filled with reports of the various "leagues."

In minor matters, the popularity of such toys as the Teddybear, that curious tribute to the worth of an American president, the spread (by seductive advertising) of the chewing gum habit, 
the establishment of the automatic chewing gum machine, that monument of progressive civilization, are all to be reckoned with. Our fashions in clothes are decreed for us in New York, whither our tailors resort yearly to ascertain "what will be worn"; and our youths develop knobbly shoulders, semi-detached trousers with permanent cuffs or hour-glass waists, according to the whim of certain multiples of nine in the commercial metropolis of America. All these are straws showing how the wind blows.

The list of such straws might be extended indefinitely. No Canadian ever invents a new slang term. All our slang is brought in and distributed by the American "shows," of one kind or another. We have imported Thanksgiving Day, a heathen festival of autumn, as Goldwin Smith points out, Labour Day, Arbor Day, Mothers' Day. As soon as our cousins south of the line decide to celebrate Great-grandmothers' Day we will uncritically adopt it too. Fate has even underlined this tendency by placing our national birthday on the First, beside the American Fourth, of July. Our very coinage bears the impress of our neighbours' customs. Our children call cents "pennies" (thus showing that the half is at least equal to the whole), and our pretty five cent silver pieces they call "nickels," after their ugly American equivalents. The government mint itself has followed the stream of tendency and issued cents the size of the American cent. Our police uniform badges and clubs are American. Our patriotic buttons-An Amerian idea-are made in Newark, New Jersey.

The wholesome but unpleasant truth has been uttered by an American historian. At the end of his True History of the American Revolution, Mr. Fisher speculates as to what Americans would have developed into had there never been any break with England. His judgment is, "We might have been a tamer, less inventive people, like the Canadians."

"Tamer and less inventive." The only way to controvert such an opinion is to point to our inventions. We invent nothing. The various fraternal orders invade us from the United States. The Rotary Club is another instance. It is, no doubt, an admirable organization, though intrigued by the title I was personally disappointed to find that the Rotarians did not rotate on their own axes like the Whirling Dervishes. But why did not a Canadian invent it? Why must we be always borrowing ideas from our big neighbour?

Reviewing all these facts the pessimist may well shake his head and sigh: "Perhaps, after all, it is not worth while struggling 
on, trying to make Canada a distinct nation. Best give up the struggle. Work along the line of least resistance. Perhaps the utmost we can ever hope to become is a poor pale imitation of the United States."

But the optimist will have his say, as well. "Confronting all these facts, and many more which might be alleged, I find that there always has been a viewless force making for national unity, not only strong enough to resist the drag towards absorption in our neighbour state, but to create a national spirit, a national character, a national unity. That spirit is now more potent, that character more clearly defined, that unity more compact than ever before. A whole set of factors have been omitted from your calculation. The test of a man's courage, energy, resource is how he acts in a sudden, unforeseen emergency, a matter of life and death. So of nations. The supreme test for Canada came in August, 1914. She did not hesitate for one moment. No doubt clouded her judgment; she saw at once the issues of the struggle as clear as the su $\mathrm{n}$ at noon-day. At once she took her side for life or death. With incredible youthful energy she hurried her first army to the relief of Mother England. Six weeks after the declaration of war, thirty-three thousand armed, equipped and organized fighting Canadians were on their way across the Atlantic. To her lovers in those great and gallant days Canada seemed the lady knight, Britomart, beautiful and terrible, hastening to the field, and buckling on her armour as she ran. Of the Canadian Army, Currie could say, as Cromwell said of his Ironsides, 'Truly, they were never beaten.' Ypres, Vimy, Passchendaele, Bourlon Wood, and a hundred other fights, bear witness to that saying. Our enemies themselves being judges, the Canadians were the shock troops of the British Army. And was there a single failure at home, behind the fighting line? Was there ever a halt in the stream of men, money, aid of every kind, pouring across the seas to their relief? In the darkest days of the great defeat, was there ever the flutter of a white flag from one end of Canada to the other? Did a single newspaper ever hint at surrender or compromise with the foe? And our glorious women-how they toiled! How nobly they bore their losses! How they tended the wounded, cared for dependents, nursed, and comforted and educated the broken men back from the war! From first to last, at home and abroad, the record is of imperishable glory. On Canada's escutcheon there is not the slightest blot. For four years Canada lived on the heights of heroism. The national spirit revealed in the 
ist

fierce storm of war was alive, if latent, before the war; it is alive now. It has the power to shape a national ideal worthy of Canada's part in the great struggle and to lift our people to its height."

Archibald MacMechan 